\title{
The Dilemma of Guarding Self-Actualization from Fear Claws
}

\author{
Dalia Mohamed Mostafa Mabrouk ${ }^{1,2}$ \\ ${ }^{1}$ Faculty of Arts \& Humanities, Suez Canal University, Ismaïlia, Egypt \\ ${ }^{2}$ General Headquarter of Police, Abu Dhabi, UAE \\ Email: dmabrouk2009@hotmail.com
}

How to cite this paper: Mostafa Mabrouk, D.M. (2019) The Dilemma of Guarding Self-Actualization from Fear Claws. Open Journal of Social Sciences, 7, 1-6. https://doi.org/10.4236/jss.2019.77001

Received: May 15, 2019

Accepted: July 7, 2019

Published: July 10, 2019

Copyright (c) 2019 by author(s) and Scientific Research Publishing Inc. This work is licensed under the Creative Commons Attribution International License (CC BY 4.0).

http://creativecommons.org/licenses/by/4.0/

\section{(c) (7) Open Access}

\begin{abstract}
My ultimate concern in this research is to investigate the culture of fear that we live in and how it impacts our vocational callings. Why the fear of failing can be immobilizing, or can paralyze us to do nothing, and therefore fall a prey to inner devastation between fulfilling our self-image belief and securing our daily responsibilities. This fear goes harshly against the inner psychological need that drives us to maximize our personal abilities and resources which may vary from one person to another. Ironically implementing the basics of organizational psychology aims to increase productivity and develop and train employees professionally. Instead there must be a huge consideration to the varied work stress that derives many to fall into deep depression. In this study I try to come closer to a clearer picture of what triggers this fear stress; is it work load or the way managers approach employees? Does a narcissist manager or any other person aggravate this stress by feeding an environment of fear that paralyzes others' talents and capabilities? Is every individual responsible for fencing his own boundaries from any external fear threat that may attack him? Or the real threat comes from one's own inner thoughts, supposing that we could easily block outer irritations.
\end{abstract}

\section{Keywords}

Self-Actualization, Self-Image, Vocational Callings, Mental Health

\section{Introduction}

The meaning of "self-actualization" is mainly derived from Humanistic psychology, specifically, from the theory created by Abraham Maslow. Self-actualization, according to Maslow, represents growth of an individual toward fulfillment of the highest needs; those for meaning in life, in particular [1]. 
Carl Rogers also created a theory implicating a "growth potential" whose aim was to integrate congruently the "real self" and the "ideal self" thereby cultivating the emergence of the "fully functioning person" [2]. It was Maslow, however, who created a psychological hierarchy of needs, the fulfillment of which theoretically leads to a culmination of fulfillment of "values" [3].

Maslow's hierarchy reflects a pattern of growth depicted in a direct pyramidal order of ascension. Moreover, he states that self-actualizing individuals are able to satisfy their needs in life through free-will and determinism. He also contributes that self-actualizers are highly creative, psychologically robust individuals.

Self-actualization is the ultimate goal of all organisms. He saw all behaviors and drives as manifestations of this overarching motivation, and self-actualization as the fulfillment of one's greatest potential. So the theory that the drive to self-actualization will only emerge as a motivator once a variety of more basic needs are met requires more consideration when the individual is trapped within certain images of fear whether real or out of his own imagination.

There are many kinds of fear as the fear of failure, the fear of divorce, the fear of leaving our job or the fear of losing security. This particular kind of fear costly prices us as individuals so much leaving us devastated between the dire need to break free from this cancerous cycle and the fact of having to pay our bills. The majority of people survive jobs which completely kill their creativity mostly because of a troubled unsecured boss or weak management. The only thing they excel in is promoting a sick work environment with a lifeless spirit. Most think that they are not in the right job for them and that those jobs don't satisfy their professional prospects and expectations. What keeps them going on is their fear of the unknown. Everybody surrounding them pushes them to give up their job fantasies, while their inner call tears them apart to act promptly. In this study, I try to contribute my thoughts in an attempt to dig deep into the secret keys of fear and how it dominates human thoughts in that mighty sovereign power.

When it comes to vocational callings, fear might be excused for a sound reason to be experienced. We need to investigate the logical ground of this calling as it could simply be a self-ego. Here the calling itself is questionable as it might delude one's reasons and leads to a wrong decision. [4] Some may be really talented to have been born with a love or passion for a certain activity or skill. In such a case, responding to a smoother transition in answering a call seems logical.

In listening to your calling, you need to continually ask yourself these questions: What urges you to continue your way? If you took money out of the equation, what really motivates you? What do you spend most of your time reading, thinking, or talking about? Relatively we somehow find that our past often drives our future as a lesson to contemplate and think where God wants you to go forward with your life.

Practically speaking, more research needs to be conducted focusing on the 
drive of fear that handicaps the senses and lock the mind from a psychological perspective with insight into my experience. I spent eight years in a private educational institution. It furnished me with a magnitude of skills, and experienced more of life in this place than I could've imagined in any other. I met with multi-national people seeking better opportunities. Throughout their dire attempts in their journey of self-actualization, they may go far beyond limits because of outer forces and internal circumstances. I met with several daunting situations and downfalls that helped me rethink about my goals in life.

\section{Discussion}

With my own drawbacks, I had the opportunity to discover myself. Several hard circumstances brings ultimate shades of strengths that exceeded my expectation about myself. I discovered that I was given a new lens and prism from which to see life. For others, the crisis could be the death of loved one, a chronic disease, a major financial hardship, getting fired, or any other life-changing experience. Continuous ups and downs is the very simple rule of life; never trust the ups and never lose your self-control in the downs. Every hardship you pass through without leaving an inner scar is a wasted opportunity to recharge your persistence of self-quest. It's via those scars that you get your values flipped out and your worldview shaken up. Your self-reliance is tested and given the chance to deepen and grow.

After long years in academic work where I held senior posts and overwhelmed in delivering lectures every day, I shifted into administrative work which I thought will be better. Being trodden a completely different work environment, I firsthand experience the real meaning of narcissist colleague and energy vampire manager and the self deluded fair leader and many others of these psychic phenomena, but for the first time began questioning my career. I felt an uneasiness and a certain disconnect between the academic life I used to and the new work I voluntarily choose. Moving to a governmental routine administrative job was like a shocking exposure I could hardly manage to survive. Adaptation is just a stressful process you strive every single day to push yourself to reach the slightest level of fitting in. I did what my mind thought at the time, which was to "shift to administrative work" [5] But the longer I stay in the administrative one, the more I felt the nagging sensation that something just felt off. Call it intuition, a gut feeling, or a sense that I don't belong here. Gradually, the desires of my heart became more distinct. I wanted to go back to where I feel myself alive, though hectic. But what was I to do? Give up a good-paying job and face unending questions from my surrounding family?

I know for a fact that growth takes time. We live in an age of instant access and demand for instant change. You may have a strong pressing concept for a new you, but before there's any tangible movement, you may spend years mulling over your ideas. Still, there will come a moment of decision and when that moment arrives, may you take that first step and walk boldly down the path set 
before you with confidence, conviction, and courage. By contemplating through these two different types of jobs, I get out with a simple fact that being satisfied with a job secure you survival, but challenging yourself for exerting extra skills guarantees you extraordinary opportunities.

Back to the drive of fear, our fear response, through a process called potentiation, is amplified if you are already in a state of fear. When we are prone for fear, even harmless events seem scary. If we are afraid of flying, even the slightest turbulence will push your blood pressure through the roof of the plane. And the more worried we are about our job security, the more we will sweat it when the boss calls us in for even an uneventful meeting.

Actions motivated by fear fall into four types; freeze, fight, flight, or fright. Freeze means to stop what we are doing and focus on the fearful stimulus to decide what to do next (e.g., you read a memo that your company will be laying off people). Next, you choose either fight or flight. You decide whether to deal with the threat directly (tell your boss why you shouldn't be laid off) or work around it (start looking for another job). When the fear is controlling all your senses, you experience fright: You neither fight nor flee; in fact, you do nothing [6]. In fact, we obsess about the layoffs, ruminate, complain, but we take no action. Being continuously in fright mode can lead to hopelessness and depression. It paralyzes the spirit, leaving us only exist not live.

\section{Conclusions}

Psychologists come to end that fear stands for "Fantasized Experiences Appearing Real" [7]. In other words, they believe that it is self-created. On the psychological level, confronting your fear instead of backing down brings about a sense of accomplishment and empowerment. Every time you confront your fear you gain power while your anxiety loses strength (I can tolerate it; it's difficult but not impossible; it's not the end of the world) [8]. Every time you confront your fear you accumulate evidence of your ability to cope. On the behavioral level, confronting your fear repeatedly helps develop skills and mastery. Mastery decreases the chance of failure and therefore reduces the need to worry.

We react differently to real and imagined threats. Imagined threats cause paralysis. Being scared about all the bad things that may or may not happen in the future triggers our worry which consequently incapacitates us from taking action. We got stuck in a state of fear, overwhelmed but not knowing what to do. Real threats, on the other hand, cause frenzy. When the threat is imminent and identifiable, we jump to act immediately and without flinching. This is why people are much more likely to change their eating habits after a serious health scare.

Fear can be as much an ally, as it can be an enemy. And fear of fear can keep one locked in a cage of insecurity. Overcoming our fears is just a skill that we need to really acquire by putting different scenarios to what threat we are encountering and trying to figure out real alternatives that save us such stressful 
moments.

It's one of the most common reasons people procrastinate on taking action toward their goals or to change their life direction. We fear failure, or rejection, or being embarrassed, or disappointing or angering other people, or getting hurt.

Finally, exposure to whatever irritating us is particularly useful on the emotional level. It was researched that many anxiety problems are at their essence a "fear of fear." Most people who fear crowds, elevators, or planes know that these objects are not dangerous. What they fear is the sensation of fear itself. Exposure to the sensations of fear allows them to habituate to these sensations, while at the same time improving their emotional literacy, since staying in the terrain helps to learn how to navigate, manage, and work it.

Exposure isn't easy. However, living in the prison of avoidance isn't easy either, and it isn't much of a life. The short-term discomfort of exposure is the price we must pay to gain a better more convenient life free of daily regrets and mental distractions.

Moreover, while most organizations are concerned about implementing organizational psychology to increase productivity and professional development, I believe that cognitive psychology is the one branch that requires greater attention. It is about exploring the branch of mental science that deals with motivation, problem-solving, decision-making, thinking, learning, memory, and attention. Simply maintain mental and psychological well-being means living among well-balanced people and getting social problems to a minimum [9]. That's why I here suggest that governments should seriously work on setting a two-dimension parallel plan for a better containment of stress, depression, fear and suicide rates as research shows significant increase in such cases which are considered to form real threats that would cost the world huge amounts of money for medication. First, accrediting a compulsory course in cognitive psychology in schools and universities. Second, tailoring regular courses of mental wellbeing and connecting them with employees' promotion in all workplaces whether public or private.

\section{Conflicts of Interest}

The author declares no conflicts of interest regarding the publication of this paper.

\section{References}

[1] Sternberg, R.J. (1994) Encyclopedia of Human Intelligence. Vols. 1 \& 2, Macmillan, New York.

[2] Squire, L.R. (1992) Encyclopedia of Learning and Memory. Macmillan, New York.

[3] Corsini, R.J. (1994) Encyclopedia of Psychology. 2nd Edition, Vols. 1-4, John Wiley, Oxford.

Goldberger, L. and Breznitz, S. (1982) Handbook of Stress: Theoretical and Clinical Aspects. Free Press, New York. 
Wolman, B.B. (1983) International Encyclopedia of Psychiatry, Psychology, Psychology, Psychoanalysis and Neurology (12 Vol.).

[4] Wilson, J.P. and Raphael, B. (1993) International Handbook of Traumatic Stress Syndrome. Plenum Press, New York.

[5] Gregory, R.L. and Zangwill, O.L. (1987) Oxford Companion the Mind. Oxford University Press, Oxford.

[6] Spielberger, C.D. (1982) Advances in Personality Assessment. Lawrence Erlbaum Associates, Hillsdale.

[7] Schaufeli, W.B. and Leiter, M.P. (1950) Annual Review of Psychology. Annual Reviews, Stanford.

[8] Alpert, A. (1945) The Psychoanalytic Study of the Child. Yale University, New Haven.

[9] Ellemers, N. Review of Behavior Therapy: Theory \& Practice. Guilford Press, New York. 